\title{
THE MAY COUNCIL MEETING IN DEKALB
}

The Council met on Sunday, May 12, 1974 in DeKalb.

The Council authorized three invitations to Colloquium Lecturers, namely

$\begin{array}{ll}\text { I. M. Singer } & \text { January 1976 } \\ \text { William Browder } & \text { August 1976 } \\ \text { Jurgen K. Moser } & \text { August 1976 }\end{array}$

The Council elected Chandler Davis to replace Jacob Feldman as a member of the Editorial Committee of the Proceedings while the latter is on temporary leave from his editional duties. [The Board of Trustees subsequently approved the election.]

The Council received the information that Fred G. Abramson and James Li-Ming Wang had been offered doctoral fellowships and had accepted. The Council voted to recommend to the Trustees that the postdoctoral fellowship program be continued for another year with continuation of the subsidy by the Society based on the same matching formula.

The Council approved a Summer Institute for the Summer of 1975 on the subject of Functions of Several Complex Variables, with Robert C. Gunning and Hugo Rossi as co-chairmen of the organizing committee and co-editors.

The Council approved a symposium, to be sponsored jointly with the Society for Industrial and Applied Mathematics, on the topic of Nonlinear Programming, with Richard Cottle as chairman of the organizing committee and editor.

The Nominating Committee, consisting of Steve Armentrout, Chairman, David M. Goldschmidt, J. J. Kohn, B. J. Pettis and David A. Sanchez, offered a slate. The Council then nominated the individuals on the slate, as follows:

Vice President (one position)

Member-at-large of the Council

(five positions)

Secretary

Associate Secretaries

Treasurer

Associate Treasurer
John W. Milnor

Cathleen S. Morawetz

Joseph L. Taylor

Arthur S. Wightman

Robert Steinberg

J. Ernest Wilkins, Jr.

David Gale

Phillip A. Griffiths

Jonathan L. Alperin

Everett Pitcher

Walter Gottschalk

O. G. Harrold, Jr.

Franklin P. Peterson

Murray H. Protter

Members of Publication Committees

Bulletin

Colloquium

Mathemdtical Reviews
Hans Weinberger

S. S. Chern

D. J. Lewis 
Mathematical Surveys

Mathematics of Computation

Proceedings

Transactions and Memoirs

American Journal of Mathematics

Committee to Monitor Problems

in Communication

Trustee
Robert G. Bartle James H. Bramble Walter Gautschi

Richard K. Miller

Daniel W. Stroock Stephen Shatz

I. M. Singer

Leonard Gillman

Robert M. Baer

Calvin C. Moore

The Council nominated Frank L. Spitzer and Joseph B. Keller to represent the Society to the Division of Mathematical Sciences of the National Research Council.

The Council approved a set of operating procedures for its Committee on Legal Aid, stating conditions under which the Committee might recommend to the Trustees that the Society lend money to an individual to facilitate legal recourse following a discriminatory injustice.

The Council recommended to the Trustees that a research-expository journal be established.

The Council confirmed the invitation to Fritz John to be the Gibbs Lecturer of 1975 .

The Council authorized the President to appoint a Committee on Teaching Loads and Class Sizes, to carry out the terms of a resolution passed at the Business Meeting of January 27, 1974.

Bethlehem, Pennsylvania

Everett Pitcher

Secretary 